\title{
MEGALITHIC SITES IN THE DISTRICT OF SINJAI, SOUTH SULAWESI, INDONESIA
}

\author{
Hasanuddin \\ Balai Arkeologi Makassar (Archaeological Institute of Makassar), South Sulawesi, Indonesia; \\ udin.balar@gmail.com
}

\begin{abstract}
Research was conducted in the Sinjai District (South Sulawesi) on three sites linked in alliance called Tellu Limpoe. The findings are mostly earthenware and ceramic fragments of various dynasties. Other findings include dakon (pit marked stones), distributions of stone of various shapes and sizes, and stone mortar with various holes of different sizes. In addition to grinding grain, these objects were also used as clean water reservoirs to meet the needs of supporting human life. All of the archaeological remains discovered indicate the dynamics of life, including household, religious, subsistence, and trade activity. The settlement system is more likely influenced by geographic factors than anything else, due to the hills and mountains that comprise the Sinjai area. The source material supports the interpretation that the natural environment provides enough (fertile) resources that can be used directly by humans.
\end{abstract}

\section{INTRODUCTION}

The concept of culture has different meanings depending on context. For some scholars culture is the sharing of knowledge and values that holds a community together, for others culture is what distinguishes one society from another. Culture is a complex system that integrates technology, knowledge and beliefs, and, in a palaeoanthropological context, represents the way of life that allowed early humans to adapt to a range of environments (Giusti 1994). With the extension of this perspective to complex chiefdoms and states, culture could be thought of as both the personality of a groupand a measure of the group's advancement along the path to "civilization" (Fagan 1995:28-32). Archaeologists seek to infer culture based on traces of material evidence recovered from sites marking the location of past human activity. This paper presents the results of archaeological investigations at three hilltop settlement locations in the Sinjai District (kabupaten), South Sulawesi. On the basis of the imported ceramics found, the sites were established by at least the 15 th century $A D$, although probably earlier. The function and interrelationship of the settlements is explored with reference to oral and historical accounts. Features of the sites continue to be places of veneration for populations living in the area today and this contemporary significance is also discussed.

Sinjai is located on the east side of Mount Lompobattang with undulating, hilly and mountainous terrain covering some $80 \%$ of its area . Earlier investigations included the survey and excavation of Batu Pake Gojeng, a megalithic site with similarities to the sites to be described here (Kallupa 1984; Darmawan et al. 1992), and the Balangnipa fort, a Dutch colonial installation which the Dutch originally captured from the indigenous Bugis population (Muhaeminah 2009). During the research on Balangnipa fort, oral history was collected on three small local kingdoms, Lamatti, Tondong and Bulo-Bulo, which forged an alliance to produce the confederation of Tellu Limpoe. Tellu Limpoe subsequently played an important role in Sinjai affairs and maintained diplomatic relationships with major South Sulawesi kingdoms such as Gowa and Bone. This information encouraged the Archaeological Institute of Makassar (Balai Arkeologi Makassar) to survey the sites of Lamatti in 2004 to 2006, and Tondon and Bulo-Bulo in 2010.

All three sites are located on hilltops with outcrops of sedimentary rock, and have megaliths fashioned from the local rock. Excavation was undertaken at Lamatti and BuloBulo where the prospects were reasonable for recovering subsurface remains. The dominant finds from the excavations were imported and local earthenware sherds. These finds cannot be regarded as a complete representation of the full range of activities practiced at these sites but they usefully complement the surface remains of megaliths. The research is motivated by cultural heritage concerns as well as an interest in the history of the Bugis kingdoms of Tondong, Bulo-Bulo, and Lamatti, which together constituted the "three powers" or Tellu Limpoe. The finds will be studied to develop a chronology of the activities that underpinned the process of 
political integration recorded for Sinjai's history and the documented remains conserved for educational purposes as a tangible record of the ancient heyday of the Sinjai kingdoms.

Three main questions are addressed by the preliminary study. First, how much variability is there in the finds from the Lamatti, Tondong and Bulo-Bulo sites? Second, what is the chronological framework for the development of these three former kingdoms? Finally, what range of activities took place at their ancient palace sites? The three main objectives of this study are the documentation of the variability of archaeological finds which will allow them to be included in the reconstruction of Tellu Limpoe's history, the assessment of the archaeological data and synthesis with environmental, historical and other relevant data, and the documentation of the diversity of activities in early historical Sinjai.

\section{METHODOLOGY}

Archaeological survey undertaken at Lamatti, Bulo-Bulo and Tondong recorded the location and attributes of megalithic remains and also involved the collection of surface artifacts. At Lamatti and Bulo-Bulo, one meter square test pits were excavated using arbitrary $10 \mathrm{~cm}$ levels (spits). Decisions on artifact collection during the survey and test pit location were based on the consideration of obtaining useful archaeological data rather than random sampling. Archaeological data were extracted through study of the recorded artifacts and ecofacts, including their contextual attributes such as stratigraphic associations with features and sedimentary matrix and their spatial distribution within the site.

\section{Conceptual Framework}

The present study adopts the conceptual framework developed by Mundardjito $(1993,2002)$ for the study of Hindu-Buddhist sites in the Yogyakarta area of Java. At the level of the site, this framework is based on the "conjunctive approach," initially formulated by Walter W. Taylor (1948) with fundamental implications for archaeological theory and practice (Fagan 1994: 49). The conjunctive approach takes account of the totality of information available from artifacts, ecofacts, archaeological features and the physical environment treated as variables for relating human activities to the natural environment within the analytical space of the individual site. In order to integrate information from different sites, Mundardjito's framework follows Chang (1968:213) in treating a culture as a social unit in terms of how humans organize themselves within their habitat covering a certain space. This archaeological focus on space and social relationships is also apparent in Fagan's (1995:19,163-167) description of the study of settlement patterns as the analysis of the adaptation of humans to their environment. Settlement patterns are affected by many factors including environment, population growth and political practices. In this perspective, spatial archaeology investigates social organization as it relates to the extraction of natural resources in the complex relationship between society and environment.

Mundardjito's conceptual framework transcends an overemphasis on the formal or chronological attributes of artifacts by treating them as units in space for understanding the use of the resources within a site. The physical connectedness of a site's artifacts can be related to the spatial distribution of the site's natural resources and so reveal the human ecology of the local community. The distribution of sites within a regional settlement pattern provides information on wider social relations and the integration of communities into larger political and religious organizations.

\section{Geographical and Geological Conditions}

Sinjai District is located on the east coast of the southern peninsula of South Sulawesi at the foot of Mount Bawakaraeng, about $223 \mathrm{~km}$ from the city of Makassar. The southern peninsula of South Sulawesi is characterized by a moist tropical climate with rainfall ranging from 1,250-3,750 $\mathrm{mm} /$ year and an average temperature of not less than $18^{\circ} \mathrm{C}$. The lowlands take up most of the west coast and a narrow strip along the south and east coasts. Geologically, Sinjai and the surrounding area are covered by alluvium, young volcanic deposits, old volcanic deposits, clastic sediments ("Celebes morasse"), sedimentary limestone and intrusive rocks, of Tertiary to recent age (Sukamto, 1975).

The Sinjai District extends from $5^{\circ} 19^{\prime} 50^{\prime \prime}$ to $5^{\circ} 36^{\prime} 47^{\prime \prime}$ South and $119^{\circ} 48^{\prime} 30^{\prime \prime}$ to $120^{\circ} 10^{\prime} 00^{\prime \prime}$ East, with a total area of 81,996 ha and a population of approximately 250,000 . It borders Bone District to the north, the Gulf of Bone to the east, Bulukumba District to the south and Gowa District to the west. Annual rainfall for Sinjai ranges from 2,772-4,847 $\mathrm{mm}$ and falls on 100-160 days per year. The dry season lasts from July to around September, after which humidity builds up until January and the rainy season starts in February. Depending on season and altitude, average humidity is recorded as $64-87 \%$, and average temperature ranges from $21.1^{\circ} \mathrm{C}$ to $32.4^{\circ} \mathrm{C}$.

Around one-third of Sinjai (38\%) is flat to gently inclined (with a slope of $0-15 \%)$, one-third (31\%) has slopes between $15 \%$ and $40 \%$, and one-third $(31 \%)$ is hilly to mountainous with slopes above $40 \%$. In terms of altitude above sea level, Sinjai has five divisions: 0-25 meters above sea level (masl) consisting of 3,788 ha, 25-100 masl consisting of 7,983 ha, 100-500 masl consisting of 45,535 ha, 500-1000 masl consisting of 17,365 ha, and $>1,000$ masl consisting of 6,569 ha.

\section{Site Descriptions}

Lamatti. The rock outcroppings scattered across the surface 
of Lamatti often have traces of human alteration such as multiple mortar holes in the same rock (Figure 1). The mortars were found to be associated with ancient burial chambers as well as fragments of imported ceramics and earthenware. A selective survey collected 36 ceramic fragments consisting of 12 rim fragments, 13 body fragments and 11 unassigned sherds, as well as 92 earthenware fragments including 63 rim fragments, 14 body fragments, a handle, a spout and 7 basal sherds. Stone artifacts were also collected during the survey, consisting of 6 jasper cores, a chert chip, a piece of petrified wood, a stone pendant, two pounding stones and a stone roller. Afragment of an iron arrowhead or blade was also collected.

Survey results document hundreds of shaped stones of various shapes and sizes carved from the outcropping rock. In addition to the stone mortars there are stone troughs, dakon (flat pitted stones) and perforated stones. The large variety of these stone features indicates that Lamatti was a complex settlement site. The dominant presence of holes sculpted into stone is typical of sites in Sinjai. One potential explanation for the holes engraved into stone is that they were used to hold water, because these engraved stones are evenly distributed across much of the site and the holes vary in their dimensions. They could be a solution to the difficulty of access to clean water on a hilltop by allowing for storage of collected water, whether rainfall or surface water brought uphill to the settlement from sources down slope.

Tondong. To find specific information on the former political importance of Tondong it is necessary to visit nearby modern settlements such as Tokka and Kolasa. Information collected from the inhabitants indicate that the Tondong kingdom had been based at Tondong desa, North Sinjai division (kecamatan) at the coordinate positions $5^{\circ} 07^{\prime}$ 49.9" South and $120^{\circ} 12^{\prime} 44.3^{\prime \prime}$ East, located 73 meters above sea level. Local informants brought the survey team to a monumental rock called "Ale Wanuae" (village center) at a site known as "Ale Tondong"(Figure 2). The monument is protected by a tin roof and is a site of worship for some local community groups. In addition, there is an Islamic grave with a fine masonry structure and headstone. The site lies on a hill with the Data River to its southwest. Few artifacts (such as earthenware or ceramic sherds) were found during the survey of Ale Tondong. The lack of surface finds is attributed to looting activities by the residents in search of antiques.

Local advisors reported that the antiquities hunters had frequently found earthenware vessels containing ashes at the Tondong site. This information corresponds to the widespread practice amongst the Bugis, prior to their conversion to Islam, of cremating the deceased and burying the ashes in jars (Druce et al. 2005). In the case of Tondong the vessels containing the ashes appear to have been earthenware. However, none of the local advisors could indicate the exact location of where the burial urns had been found, and instead explained that virtually the entire surface of the site had been dug up during the search for antiques.

Bulo-Bulo. Bulo-Bulo (Figure 3,4) is mentioned as an important polity in the production of South Sulawesi historical manuscripts known as lontarak, in reference to the palm leaf strips on which the earliest of these manuscripts were written. Bulo-Bulo is located east of Tondong in the Ale Wanuae desa, North Sinjai with positional coordinates of $05^{\circ}$ $07^{\prime} 53.8^{\prime \prime}$ South and $120^{\circ} 13^{\prime} 08.6^{\prime \prime}$ East. It occupies the top of a hill 156 meters long, 44 meters wide and 102 masl on the north side of the Data River (Figure 3). The site can be reached via paved road to Topekkong followed by a climb to the north or by asphalt road to Ale Wanuae and a walk to the southwest.

Eight outcrops of sedimentary rock can be identified on Bulo-Bulo hill amongst the trees and alang-alang grass that have overgrown the site. These outcrops constitute an

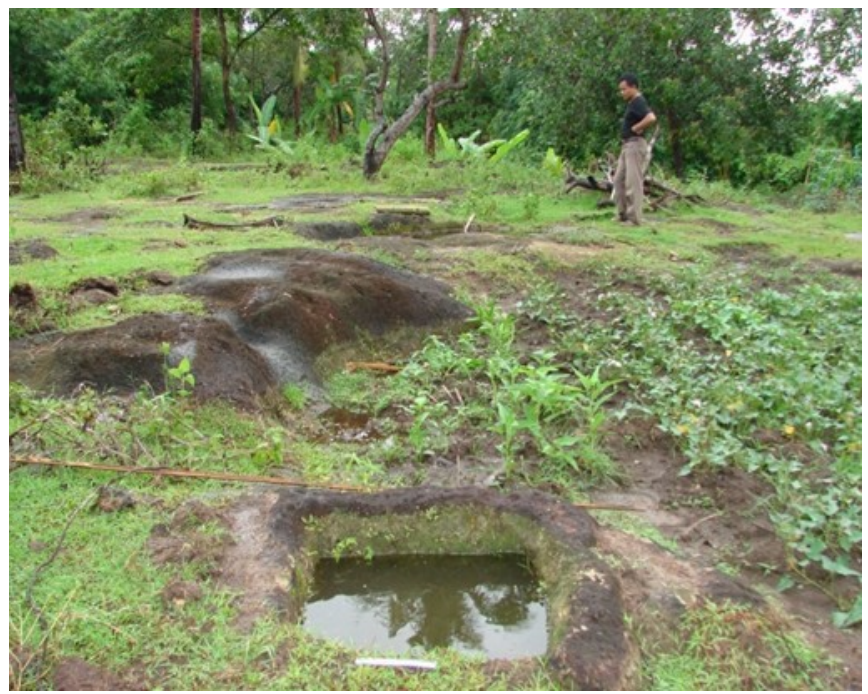

Figure 1. Typical megalithic finds from the Lamatti site including a stone trough (front) and a multiple mortar (rear).

abundant resource for mortar stones and are pockmarked by holes varying in shape, size and number. The shape typically varies from round to square, for instance, the seven round holes and single rectangular hole recorded at one rock outcrop of three meters diameter (Figure 5). Another outcrop has a conical hole with a diameter of $90 \mathrm{~cm}$ and a depth of $170 \mathrm{~cm}$, and was possibly used as a water storage container when the site was a settlement. The same rock outcrop also has a square hole with dimensions of $75 \times 75 \mathrm{~cm}$ and a depth of $60 \mathrm{~cm}$.

Many holes are filled with soil and contain fragments of pottery and other finds such as animal bone fragments (Figure 6). This shows that the holes are not in contemporary use as mortars. The cultural materials in the mortar holes 
have likely been displaced from the occupation surface adjacent to the mortars as a result of looting activities by treasure hunters ${ }^{1}$. They represent habitation debris from the period of settlement and are similar to the finds recovered from the two excavated test pits.

Sixteen meters east of the eastern test pit, we discovered a "stone well" of $135 \mathrm{~cm}$ diameter and $175 \mathrm{~cm}$ depth, filled with water (Figure 7). The well is lined with chunks of the same sedimentary rock as the stone mortars. The wall has cracks as wide as $27 \mathrm{~cm}$ which may have functioned to channel water into the well. Slightly further east, 28 meters from the test pit, we found a stone altar enclosed by a fence and protected by a tin roof. Just outside the fence is a stone outcrop with five holes. Until today the altar is a focus for worship as indicated by the presence of pandanus leaves left as ceremonial offerings. The reason why people treat the offering stone as sacred is not yet clear but according to some accounts it is the stone tomb of the founder of Bulo-Bulo village $^{2}$.

Some of the stone mortars found on Bulo-Bulo hill had to have their surface cleaned to determine the number of holes and their layout. Among these is a mortar stone measuring $12 \times 6$ meters with 42 holes of diameter 10 to 55 $\mathrm{cm}$ and an average depth of $70 \mathrm{~cm}$ (Figure 8). The mortar is located on the west peak of Bulo-Bulo hill. All around it are round "stone wells" with an average diameter of 40-55 cm. At the far west of Bulo-Bulo hill is a pitted stone or dakon. It has five pit marks on both the left and right sides and a single hole at both ends (Figure 9). The dakon stone has been provided with a tin-roof shelter by the community for its maintenance. Another dakon stone was recorded at the far east of Bulo-Bulo hill (Figure 10).

Topekkong Agreement Site. Another site closely related

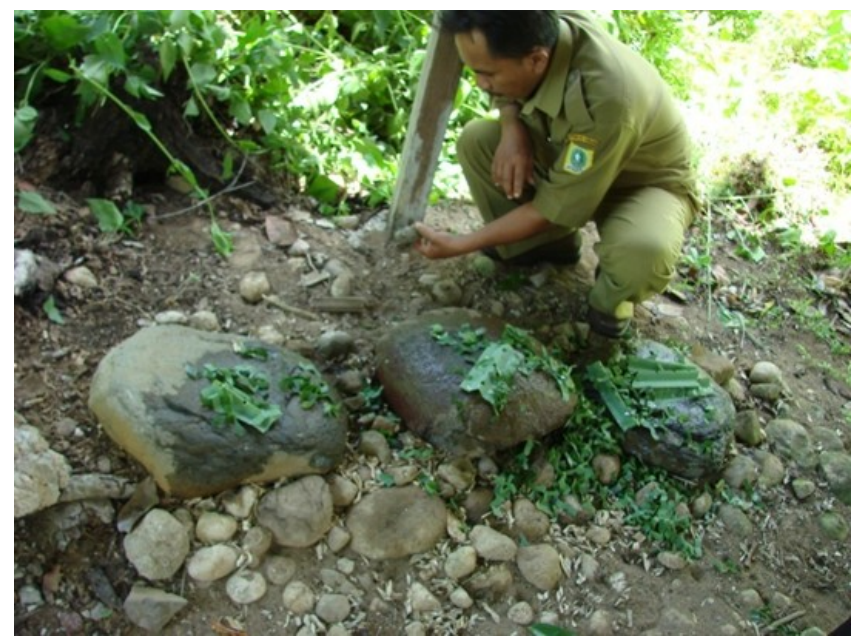

Figure 2. Some of the flat stones associated by the local community with the Tondong Ale Wanuae village center. to the history of the three kingdoms discussed here is the Topekkong Agreement Site located in Biring Ere desa, North Sinjai with positional coordinates of $05^{\circ} 08^{\prime} 05.5^{\prime \prime}$ South and $120^{\circ} 15^{\prime} 11.7^{\prime \prime}$ East. It lies to the east of the Data River at an altitude of 29 masl in the general vicinity of the Tondong and Bulo-Bulo sites. Access to the site is possible via asphalt roads to the village of Taipa, followed by a walk to the southwest of about 200 meters. The site includes the inauguration place of former rulers, inscriptions which record the content of the Tellu Limpoe agreement, and a menhir which symbolizes the agreement (Figure 11). The site is protected by the Sinjai District government.

According to the Lontarak Sinjai (Anonymous 1981), in AD 1561 Bulo-Bulo, Tondong and Lamatti agreed to enter into an agreement to form the Tellu Limpoe (three powers) confederation. This agreement took place at the instigation of king of Bone, Latenrirawe Bongkange, and marked a royal alliance with Bone. The formalized agreement, known as the Lamung Patue ri Topekkong, occurred in February 1564. The Chronicle of Bone (Macknight and Mukhlis, in prep.) also dates the establishment of the Tellu Limpoe to the early reign of La Tenriwawe Bongkangnge, which commenced in the 1560s. However, Tellu Limpoe then became a vassal of Bone, according to the Bone Chronicle, associated with the expansion of Bone's territory to immediately south of the Tangka River.

In 2000, the Sinjai government protected the site where the agreement took place. The contents of the agreement are now set out in inscriptions placed around the site, two in Bugis written in both the Bugis lontarak script and Latin script, and one in English written in Latin script. At the west of the inscriptions is a standing stone $43 \mathrm{~cm}$ high and $31 \mathrm{~cm}$ wide which symbolizes the Tellu Limpoe agreement.

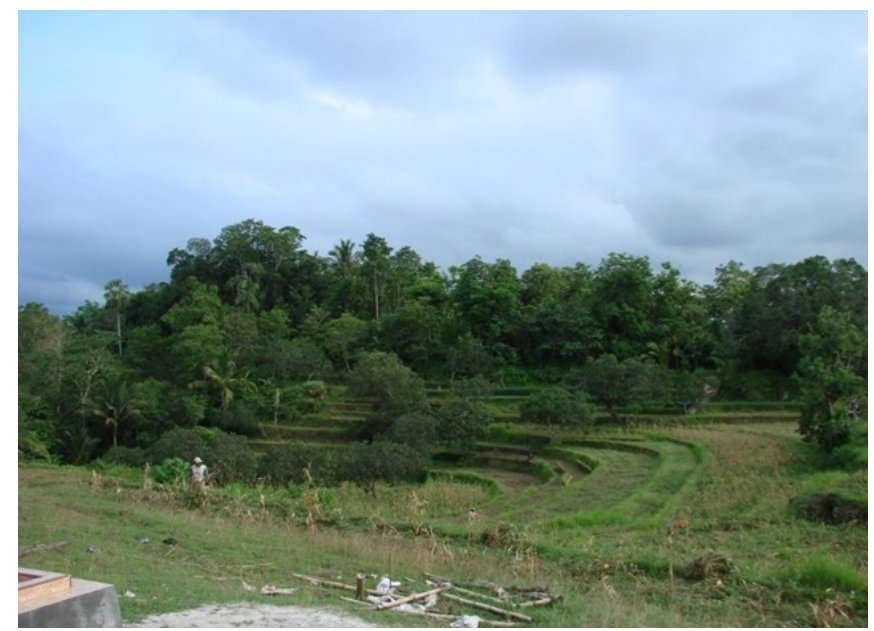

Figure 3. Location of Bulo-Bulo hill. 


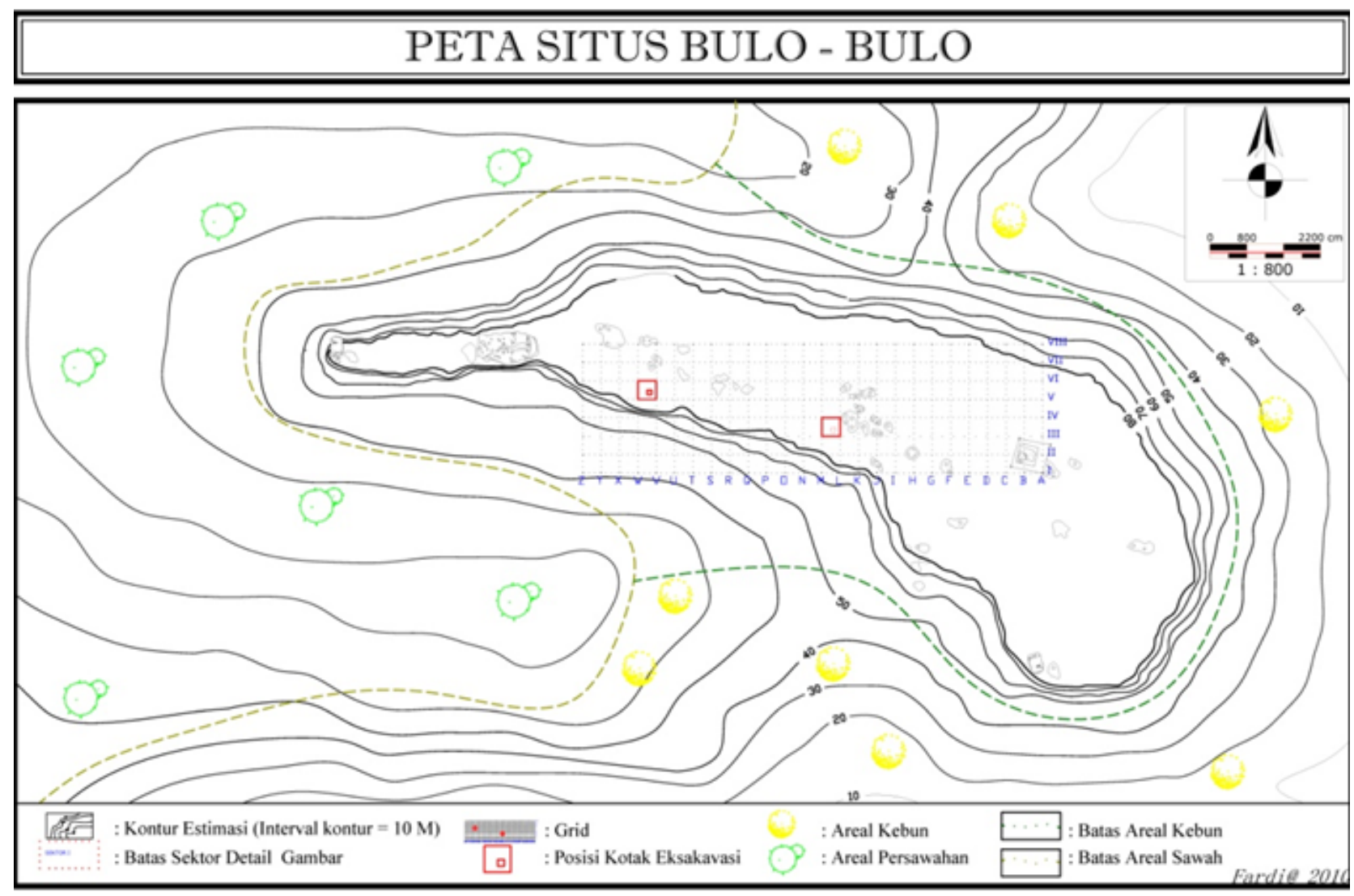

Figure 4. Bulo Bullo site map.

\section{Chronology}

According to the Lontarak Sinjai, the first ruler, Manurung Tanralili or Puatta Timpae, was based at Timpae Tana (To Pasaja). His descendants founded the kingdoms near the river - Tondong, Bulo-Bulo and Lamatti - which later united to form the Tellu Limpoe federation. Each of these kingdoms retained their autonomy but their pact allowed them to coexist peacefully. There were also other kingdoms in the Sinjai highlands namely Turungeng Sinjai, Manimpahoi, Felt, Pao, Manipi, Like, and Bala Like. These kingdoms joined together to form the Pitu Limpoe federation. In Bugis the word sijai means "seams" or "strings" and so the name Sinjai appears to reflect a reality that the many kingdoms of the district were closely intertwined.

Five ceramic sherds have been identified from BuloBulo including a c. 13th century Sung sherd and Vietnamese sherd (14th-15th centuries), Ming stoneware (15th-16th centuries) and 16th century Ming sherds. Based on the ceramics, Bulo-Bulo had been established by at least the 15th century and probably earlier. While these sherds are from wares that probably had a practical purpose, imported ceramics would have been luxury items and markers of high social status at the time of their use.

High-fired ceramics would have been imported to Sinjai, reaching Bulo-Bulo probably via the Tangka River and Data River which are not far from the site. The ceramic finds indicate that the Bulo-Bulo inhabitants had wider trade relations, although it is not clear what they exchanged in return, although locally made earthenware is one possibility. Of relevance in this context is the wider array of ceramics of approximately 16th to 18 th century antiquity identified from Batu Pake Gojeng, near the Topekkong Agreement Site including Sawankhalok and Sukothai wares from Thailand, and Ming, Swatow and Qing wares from China (Darmawan et al., 1992). These wares span the period of operation of the Tellu Limpoe confederation, and point to trade relations with other regions. The mouth of the Tangka River was probably the point of access to maritime trade for Tellu Limpoe, by analogy with the importance of the Jeknekberang river mouth for Makassar's trade and the Siang river mouth for Siang's trade before that (Fadillah and Mahmud, 2000). The Cenrana River (to the north of Sinjai) was the main artery for trade from the Gulf of Bone to the Bugis' rice-producing lowlands, and its mouth was controlled by Bone between the mid-16th and late 18th centuries (Bulbeck and Caldwell, 2000: 83; Wallis, 1965). Sinjai's share of the maritime trade in the Gulf of Bone would have been minor, but the volume of this trade would have stimulated economic activity in Sinjai. Hence it 


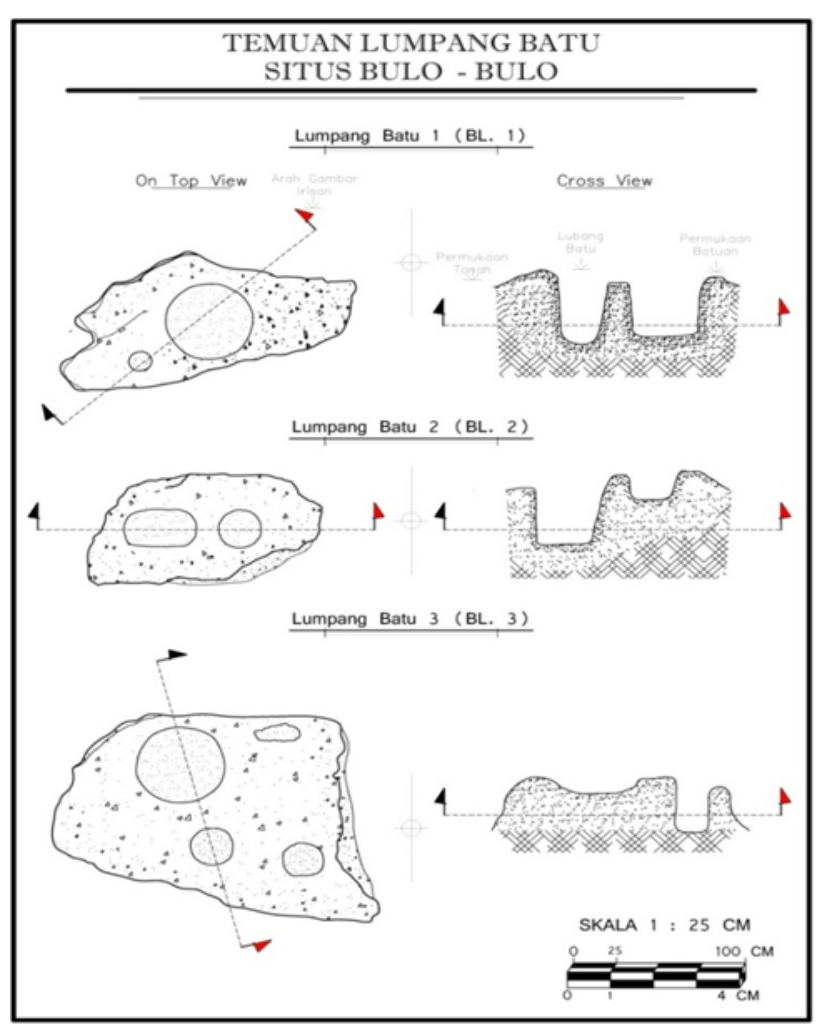

Figure 5. Examples of stone mortars on Bulo-Bulo site

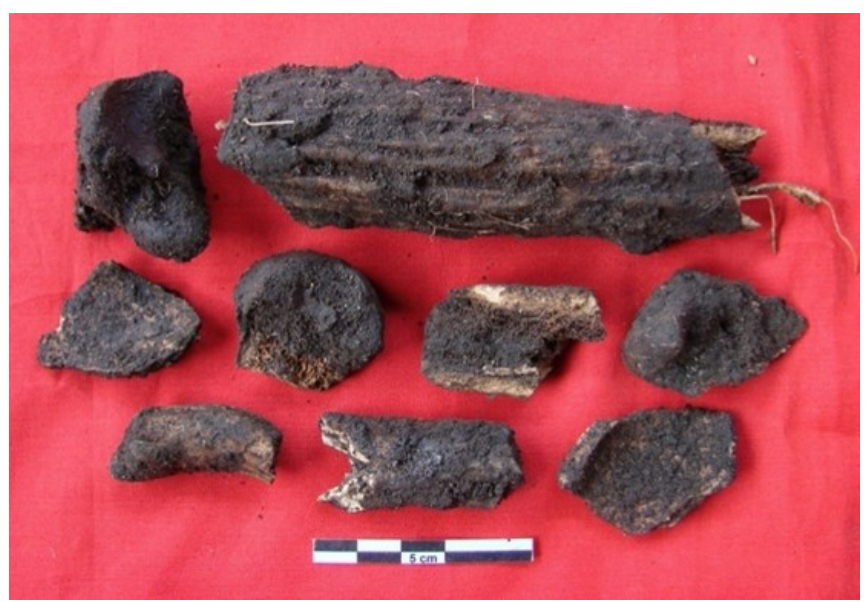

Figure 6. Animal bone fragments representing dietary refuse of the Bulo-Bulo community.

is likely that Tellu Limpoe had a port on the Tangka River, with flow-on trade to Lamatti, Tondong and Bulo-Bulo via the Data River, although the survey work to identify Sinjai's river ports has not yet been undertaken.

\section{Variety of Activities}

Household Activities and Rituals. An archaeological site can

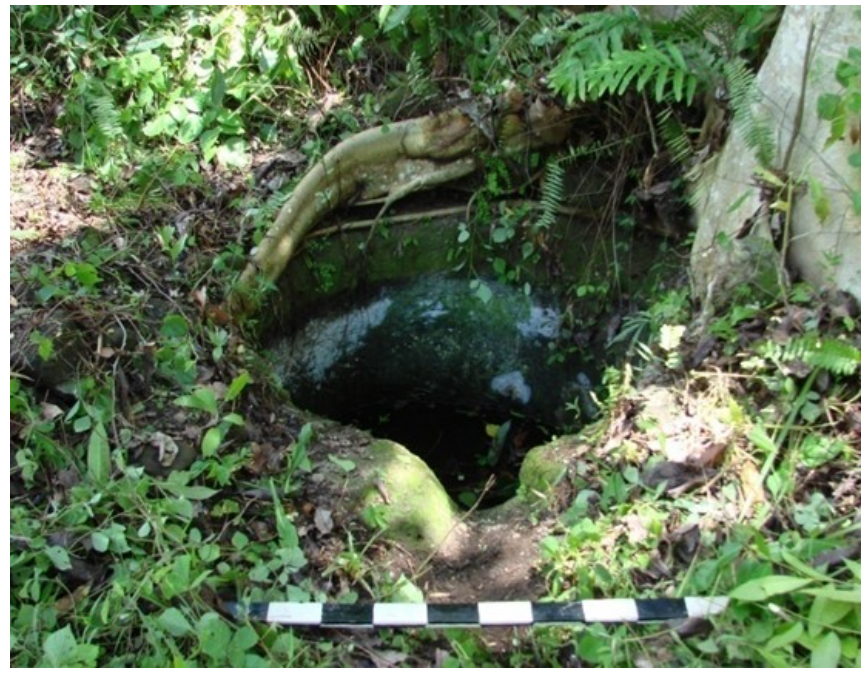

Figure 7. Stone well of $135 \mathrm{~cm}$ diameter and $175 \mathrm{~cm}$ depth among tree roots.

be viewed as a settlement where the inhabitants behaved in certain ways marked by a systemic set of activities during the time of occupation. Behavior involves both individual and community activities and the materials used in those activities. Therefore, behavior establishes a pattern for the relationships to be found between artifacts as the result of their use in systemic activities. Accordingly, the functional purpose of artifacts should be interpreted through their archaeological context, paying attention to communal activities as well as individual activities. Based on this perspective, the archaeologist analyzes the artifacts from the settlement with the aim of identifying their variability, relating this variability to particular types of activities, and interpreting the artifacts' spatial distribution and other

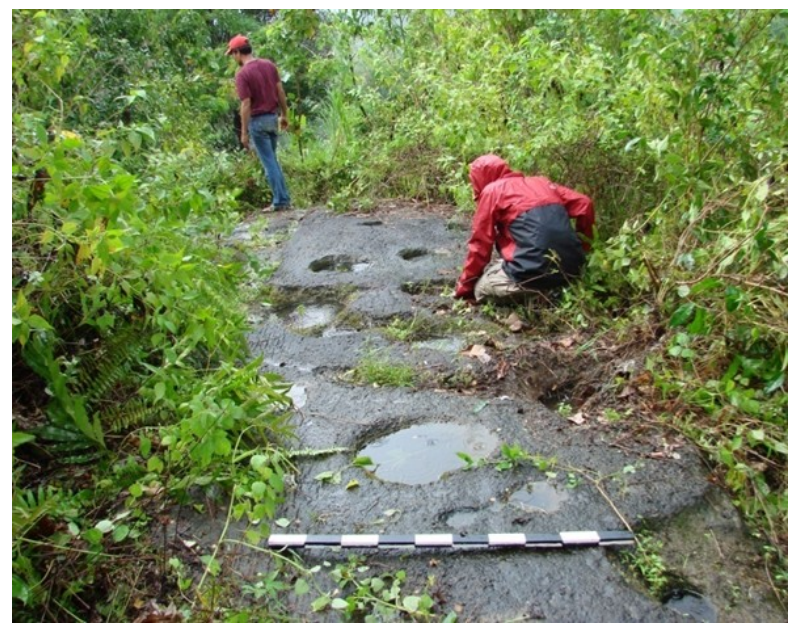

Figure 8. A mortar stone measuring $12 \times 6$ meters with 42 holes. 


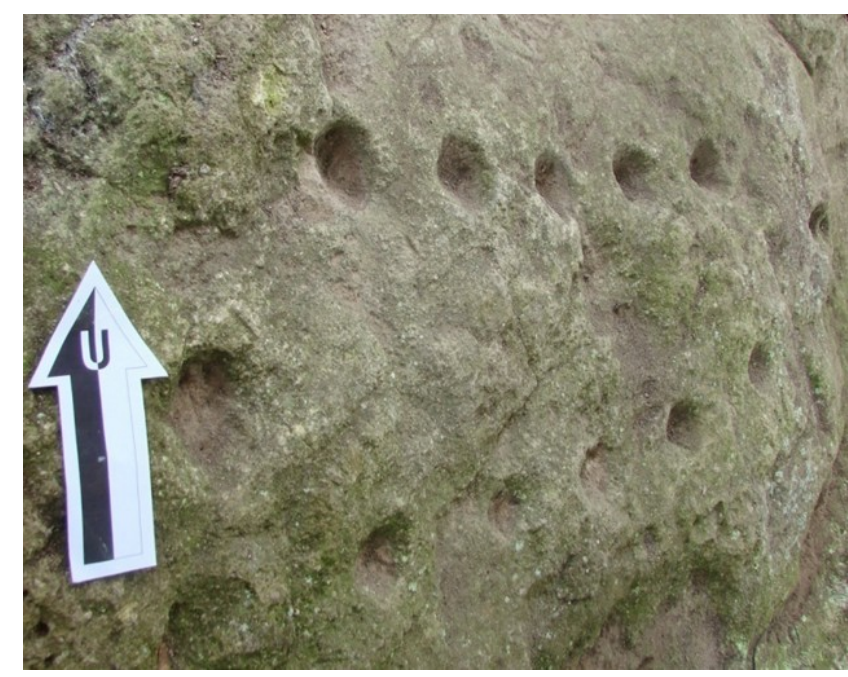

Figure 9. The layout of five holes on the left side, five on the right side and one hole at both ends on one of the pitted dakon stones.

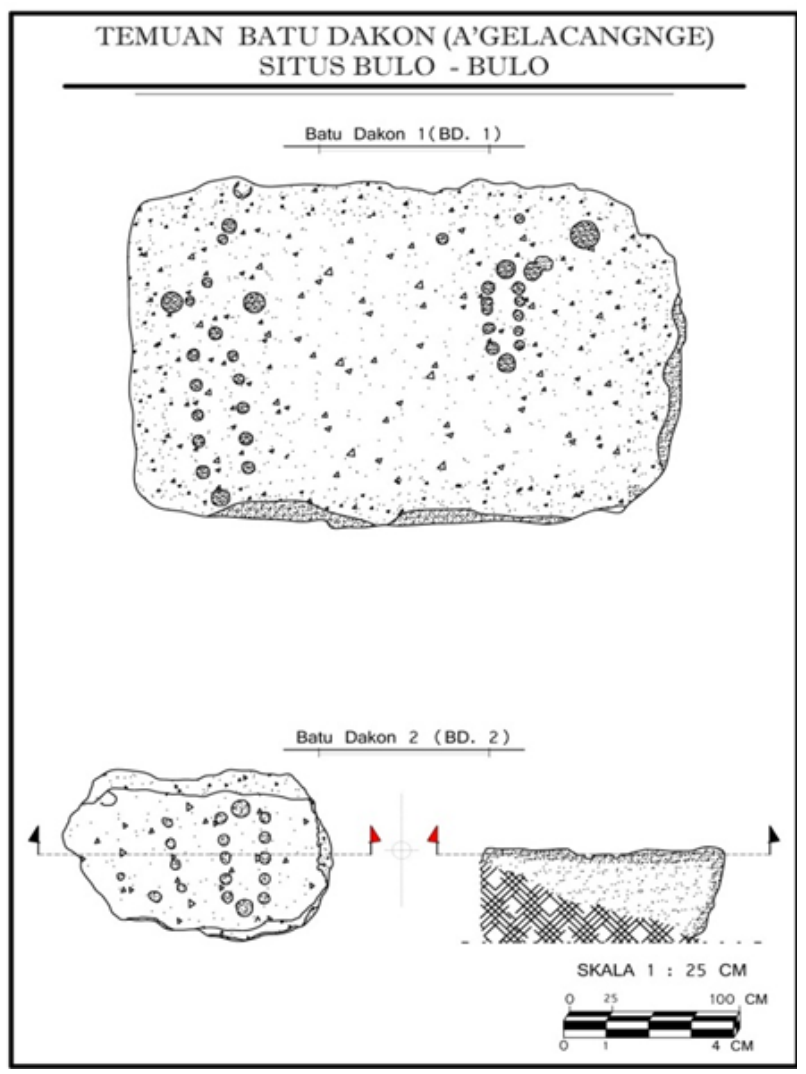

Figure 10. Diagram of the pitted dakon stones at Bulo -Bulo contextual relationships to reconstruct systemic behaviour at the settlement (Hasanuddin, 2001).

The two main artifact classes that provide an insight into systemic behavior at the Tellu Limpoe sites are the megalithic facilities and pottery sherds. Both are valuable for reconstructing everyday activities and ritual activities, as well as the role of ritual in governing household behavior. The formal attributes of the stone facilities indicate their functions and the activities pursuant to those functions, as for example the stone wells, mortars and altar at Bulo-Bulo. Traditions associated with the megaliths assist behavioral interpretation, as in the case of Bulo-Bulo's dakon stone (see below) and the ancestor cult associated with the altar. Earthenware fragments easily but it withstands heat and the sherds are resistant to weathering. The sherds can be assigned to vessel part - for instance, handle, cover, rim, spout, body and base and the application of standard analytical techniques allows jars, plates, bowls and other vessel forms to be identified. Soot was identified on the exterior of several sherds,

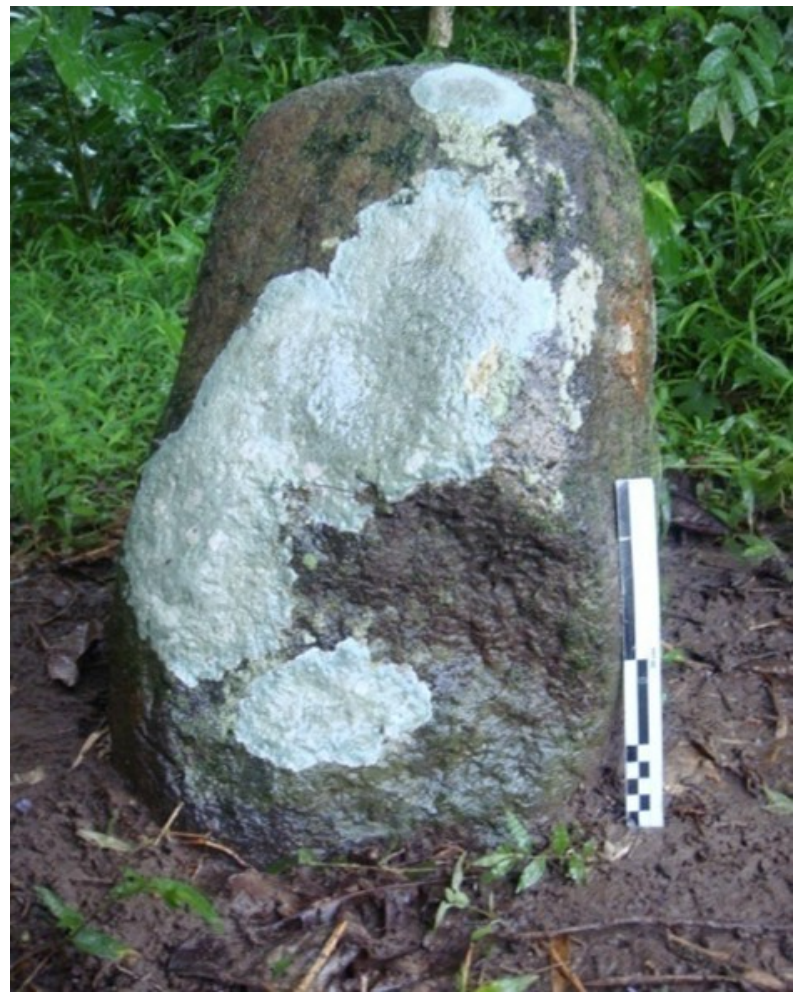

Figure 11. The upright stone (menhir) that symbolizes the Tellu Limpoe agreement.

testifying to the vessels' use for cooking (Figure 12). A contextual association observed between sherds and animal bone fragments suggests the use of pottery containers during ritual feasting. In addition, while not abundant, decorated pottery was probably reserved for special purposes, 


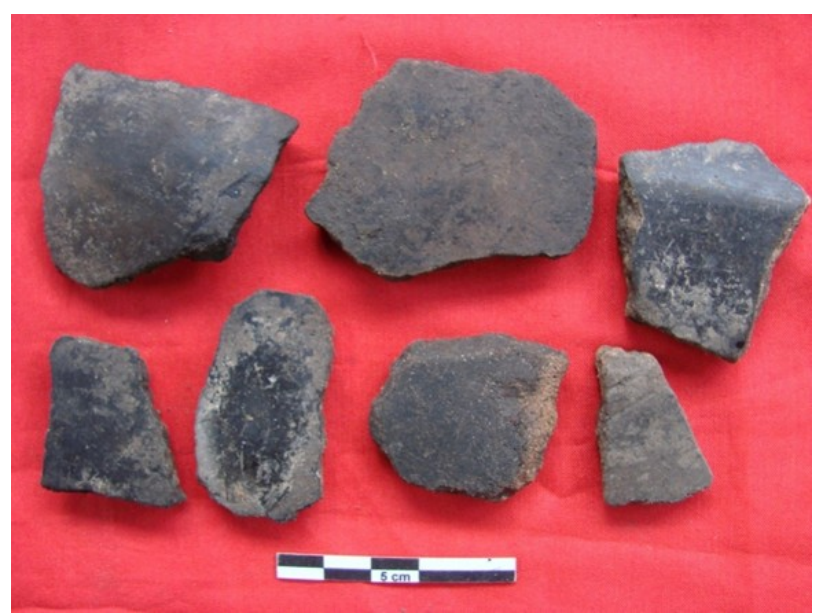

Figure 12. Soot on pottery fragments as an indication of household activity.

particularly the interesting variant that involved fields of punctate marks circumscribed by incised lines.

Preservation conditions are not ideal for finding traces of all of the activities undertaken at the Tellu Limpoe sites, but fortunately the testimony of historical linguistics assists archaeological inference in this regard. According to Bellwood (2000), about 4,500 years ago Austronesian speakers introduced agriculture when they migrated south from Taiwan through the Philippines, Borneo and other islands of the Indo-Malaysian Archipelago. They brought knowledge, skills and abilities such as maritime technology, making houses on stilts, and the manufacture of bark cloth, pottery, polished stone axes and shell ornaments. Their food production system included root crops (taro, yams), grains (including millet), breadfruit and domesticated dogs and pigs. Reconstruction of these Austronesian foundations and descendant cultures in the Indo-Malaysian Archipelago relies largely on evidence from Austronesian historical linguistics, correlated with the archaeological record (Bellwood 2000). Worship of ancestral spirits was also part of the founding Austronesian ideology (Bellwood 1996) although its expression though a megalithic tradition evidently dates to the last two millennia (Bellwood 2000).

Subsistence activities. The Bulo-Bulo, Tondong and Lamatti megalithic sites characterize Austronesian settlement in Sinjai which is continued till today by the traditional communities located in villages near the sites. While humans in general adapt to and utilize the environment to meet their needs, settled community life involves focused exploitation of environmental resources so as to improve the standard of living. In villages based on agricultural subsistence, the inhabitants lived in a rich social environment and regularly carry out corporate social activities designed to cement mutual cooperation. Corporate knowledge maintains the skill base necessary to manufacture agricultural equipment, understand the seasons and select fertile land.

Archaeological evidence for agricultural subsistence comes from the stone mortars at Bulo-Bulo and Lamatti. Bugis ethnography documents the use of mortars for intensive grain processing, leaving a smoothed surface to the mortar's conical hole, matching the recorded mortars widely distributed across Bulo-Bulo. Another probable use of the mortars was for processing local medicinal plants.

The pitted dakon stones may also have been involved in managing agricultural activity. Dakon stones are found widely across South Sulawesi, but the shape and number of holes varies, and this variation suggests a range of functions. The traditional game still played in some areas in Indonesia uses 50 seeds or small stones stored in the holes at the left and right ends. The two players alternate in filling the other holes with a seed (or stone), up to five per hole. This would have been the game played on the Bulo-Bulo dakon based on their two holding holes (one at each end) and ten other holes in between them (Figure 8). However, the strategic location of the two Bulo-Bulo dakon at the east and west ends of the hill points to a serious purpose, perhaps related to the calculation of optimal days for agricultural activities.

\section{CONCLUSIONS}

Bulo-Bulo and other settlement sites within the realm of the former Tellu Limpoe confederation in Sinjai contain archaeological traces of household, subsistence and religious activities. The variability of the archaeological record indicates a wide variety of activities and a rich, dynamic lifestyle. The religious dimension is represented by megaliths with ritual associations such as the Bulo-Bulo altar stone where cult activities are still frequently performed. The stone mortars spread across Bulo-Bulo and Lamatti are indicative of the intensive processing of agricultural products. Pottery and faunal refuse reflect the importance of consumption activities (acquiring, storing, cooking and serving food and beverages) for day-to-day survival.

The hills and mountains of Sinjai had a substantial effect on the settlement system. The settlements were located so as to take advantage of fertile land, use of the rivers near the sites as transportation routes, and the availability of rock outcrops on the hilltops to create megalithic facilities. The sites are located close to each other and the communities would have been linked through social relations including kinship ties which sustained a network of shared descent.

The Sinjai sites exemplify the Austronesian foundations of present-day Sulawesi cultures. The Austronesian legacy explains the similarities in traditional farming systems, religious systems and other cultural domains found across South, West and Southeast Sulawesi. With the passage of time, cultural diversity has emerged, as charted by archaeological sites like those in Sinjai. The Sinjai sites 


\section{HASANUDDIN: MEGALITHIC SITES IN THE DISTRICT OF SINJAI}

therefore have significant heritage value for their part in tracing Austronesian ethnogenesis and the interwoven relationships of past Austronesian communities, which in combination form the foundation of the national culture of the archipelago of Indonesia (Simanjuntak 2008).

\section{NOTES}

1. In support of this inference, local community members (such as Alimuddin of Ale Wanua, 38 years old, and Sunusi of Biring Ere, 70 years old) reported that certain people use the Bulo-Bulo area to look for antiques in addition to its legitimate use for farming. Local crops include maize and peanuts as well as rice.

2. One of our informants, Andi Ahmad Beko of Taipa village, Biring Ere (105 years old), reported that the stone at the top of Bulo-Bulo is the tomb of a former king. However, none of our informants knew the name of the man reportedly buried there.

\section{REFERENCES CITED}

Anonymous. 1981. Lontarak Sinjai. Koninklijk Instituut voor Taal-, Land- en Volkenkunde microfiche no. 3672/1986. Leiden.

Bellwood, Peter. 1996. "Hierarchy, founder ideology and Austronesian expansion". In James J. Fox and Clifford Satther (eds.), Origins, Ancestry and Alliance: Explorations in Austronesian Ethnography, pp. 18-40. Canberra: The Australian National University.

2000. Prasejarah Kepulauan Indo-Malaysia. Revised edition. Translated by Daud Tanudirjo. Jakarta: PT. Gramedia Pustaka Utama.

Bulbeck, David and Ian Caldwell. 2000. Land of Iron: The Historical Archaeology of Luwu and the Cenrana Valley. Results of the Origin of Complex Society in South Sulawesi Project (OXIS). Hull: University of Hull Centre for South-East Asian Studies.

Chang, K. C. 1968. "Major aspects of the interrelationship of archaeology and ethnology", Current Anthropology 8(3): 227-243.

Darmawan Mas'ud Rahman, Muhammad Ramli and Abdul Rifai Husain. 1992. Taman Purbakala Batu Pake Gojeng di Kabupaten Sinjai. Makassar: Balai Arkeologi Makassar.

Druce, Steven, David Bulbeck and Irfan Mahmud. 2005. "A transitional Islamic Bugis cremation in Bulubangi, South Sulawesi: its historical and archaeological context", Review of Indonesian and Malaysian Affairs 39: 1-22.
Fadillah, Moh. Ali and M. Irfan Mahmud. 2000. Kerajaan Siang Kuna: Sumber Tutur, Teks and Tapak Arkeologi. Makassar: Balai Arkeologi.

Fagan, Brian M. 1995. In the Beginning: An Introduction to Archaeology. Eighth edition. New York: HarperCollins College Publishers.

Giusti, Francesca. 1994. "Evolution of human culture: a composite pattern". In R. Allen Gardner, Beatrix T. Gardner, Brunetto Chiarelli and Frans X. Plooij (eds.), The Ethological Roots of Culture. Dordrecht: Kluwer Academic Publishers.

Hasanuddin. 2001. "Pola pemukiman dalam arkeologi: Rekonstruksi ekologi, kebudayaan dan struktur masyarakat", Walennae IV (7): 5-13.

Kallupa, Bahru. 1984. Taman Purbakala Batu Pake Gojeng Kabupaten Sinjai Sulawesi Selatan. Makassar: Suaka Peninggalan Sejarah dan Purbakala Sulawesi Selatan.

Macknight, C.C. and Mukhlis. In prep. The Chronicle of Bone. Typescript.

Muhaeminah. 2009. "Benteng kolonial Belanda di Balangnipa Kabupaten Sinjai”. Walennae XI (1), 51-64.

Mundardjito. 1993. Pertimbangan Ekologi dalam Penempatan Situs Masa Hindu-Buda di Daerah Yogyakarta Kajian Arkeologi Ruang Skala Makro. Unpublished M.A. thesis. Jakarta: Program Pascasarjana Universitas Indonesia.

2002. Pertimbangan Ekologis Penempatan Situs Masa Hindu-Budha di Daerah Yogyakarta. Jakarta: Wedatama Widya Sastra. École Française D' ExtrèmeOrient.

Simanjuntak, Truman. 2008. "Austronesian in Sulawesi: its origin, diaspora, and living tradition". In Truman Simanjuntak (ed.), Austronesian in Sulawesi. Jakarta: Center for Prehistoric and Austronesian Studies.

Sukamto, R. 1975. Peta Geologi Indonesia, Lembar Ujung Pandang, Benteng dan Sinjai. Bandung: Geological Research and Development Center.

Taylor, Walter W. 1948. A Study of Archaeology. Menasha, WI: American Anthropological Association.

Wallis, Helen (ed.). 1965. Carteret's Voyage Round the World 1766-1769. Volume II. Cambridge: University Press (published for the Hakluyt Society). 